seeds germinate both in darkness and in the light, and secondly that in reciprocal crosses of light. needing and indifferent types the effect could not be due to the testas but must be due to either the embryo or the endosperm.

H. W. HowaRD

A. G. LYoN

School of Agriculture, Cambridge.

April 5.

${ }^{1}$ Airy Shaw, H. K., Kew Bull., No. 1, 39 (1947).

- Howard, H. W., and Manton, I., Ann. Bot., N.S., 10, 1 (1946).

Honing, J. A. Genetica, 12, 441 (1930).

\section{Organic Acids of the Apple Fruit}

IT has generally been assumed that the only carboxylic acid present in the fruit of Bramley's Seedling apple is malic acid; but in 1949, when examining chromatograms run in $n$-butanol-formic acid-water $\left(40: 10: 50 \mathrm{v} / \mathrm{v}^{1}\right)$ of methyl alcohol extracts of pulp tissue of young Bramley's Seedling apples, we noted that several spots having an acid reaction to bromophenol blue appeared on the chromatograms.

In addition to a relatively large spot corresponding with malic acid $\left(R_{F}=0.49\right)$, there appeared a second well-defined spot $\left(R_{F}=0 \cdot 18\right)$ and traces of a third spot $\left(R_{F}=0.07\right)$. It was possible to wash some of the acid $\left(R_{F}=0.18\right)$ from the chromatogram and carry out tests on the solution so obtained. The acid gave a strongly positive citrazinic acid test ${ }^{2}$, given also by citric and aconitic acids. The $R_{F}$ value of the unknown acid was, however, quite different from citric acid $(0 \cdot 40)$, aconitic acid $(0 \cdot 74)$ and isocitric acid lactone (two spots, $0 \cdot 64,0 \cdot 69$, probably due to stereoisomerism).

From the $R_{F}$ values obtained under carefully controlled conditions at $20^{\circ} \mathrm{C}$., the $R_{M}$ values $^{3}$ $\left[\log \left(\frac{1}{R_{F}}-1\right)\right]$ of the new acid $(+0 \cdot 66)$, citric acid $(+0 \cdot 18)$ and tricarballylic acid $(-0 \cdot 31)$ were found to differ by almost equal amounts $\left(\Delta R_{M}=0.48\right.$, 0.49 ) and suggest a stepwise addition of hydroxyl groups to tricarballylic acid. It would appear, therefore, that the new acid might well be a dihydroxy tricarballylic acid.

The acid appeared to decrease in amount as the fruit ripened and also appeared to be present in the pulp of the fruit of peach and plum.

One of us (A.C.H.) has since examined other varieties of English apples for the presence of the new acid. It has been found in much greater quantity in young Worcester Pearmain and young Cox's Orange Pippin apples. In order to study its chemistry, an appreciable amount of the acid has now been obtained from young Worcester Pearmain apples. The fruit was extracted with cold 80 per cent alcohol and the alcohol removed by evaporation. Aminoacids and bases were removed from the resultant aqueous solution by passing it down a column of 'Zeo Karb 215', and the carboxylic acids were absorbed from the filtrate on a column of 'Deacidite E'. Displacement of the acids from this column with $0.1 \mathrm{~N}$ hydrochloric acid gave several hundred milligrams of the new acid (as the lactone) free from malic acid and chromatographically homogeneous. The chemical characterization of the acid will be described elsewhere.

Ditton Laboratory,

A. C. Hulme

East Malling, Kent.

T. Swarn

Low Temperature Research Station, Downing Street, Cambridge. April 10.

${ }^{1}$ Lugg, J. W. H., and Overell, B. T., Aust. J. Sci. Res., 1 A, 98 (1948). ${ }^{2}$ Feigl, F., and Anger, V., Microchemie, 11, 35 (1935).

${ }^{3}$ Bate-Smith, E. C., and Westall, R. G., Biochem. Biophys. Acta, 4, $427(1950)$.

\section{Formation of Green Pigment in Grasshoppers}

THE factors which lead to the production of green pigment in grasshoppers are still in doubt. Some authors ${ }^{1-3}$ claim that the deposition of green pigment, like that of grey, orange and brown, is determined by the background; others ${ }^{4-8}$ have found that the background is without effect. Faure ${ }^{5}$ obtained green individuals only when they were fed on growing grass in a humid atmosphere.

Observations carried out in the University of Ankara during 1949 and 1950 support the findings of Faure. Yellow hoppers of Acrida turrita were reared in green cages. When fed on growing grass, 69.8 per cent became green; when fed on cut grass changed every other day, 10.9 per cent became green ; when fed on dry grass, none became green. If green hoppers were kept in green cages and fed on dried grass, only 21 per cent remained green; whereas if they were fed on growing grass, 78 per cent remained green.

Similar results were obtained with the hæmolymph. The hæmolymph of yellow hoppers collected from dry grassy places is yellowish or colourless, never green. In green hoppers collected from areas of green grass the hamolymph is green in 90 per cent of them. If the yellow hoppers from the former locality are fed on green grass, the hæmolymph gradually becomes green, and after moulting the integument becomes green. The green pigment thus appears in the blood before it is deposited in the integument.

The green pigment is known to be a combination of a yellow carotene-protein with a blue bile pigment protein ${ }^{7-9}$. The appearance of green individuals depends on the formation of bile pigment. It seems possible that this pigment is derived from the break. down of chlorophyll and that for some undetermined reason this happens only when the grasshopper feeds on fresh growing grass. It is noteworthy that the excreta contain a large amount of free magnesium in hoppers of both colours.

It is hoped to confirm and extend these results in further laboratory experiments.

Department of Zoology,

University of Cambridge. April 16.

${ }^{1}$ Chauvin, Ann. Soc. ent. Fr., 110 (1941).

- James, Canadian Ent., ry (1944).

Ergene, Z. vergl. Physiol., 32 (1950).

- Przibram, Arch. Entmech., 23 (1907).

5 Faure, Bull. Ent. Res., 23 (1932).

- Hertz and Imms, Proc. Roy. Soc., B, 122 (1937).

7 Junge, Hoppe-Seyl. Z., 268 (1941).

${ }^{8}$ Okay, Nature, 155, 635 (1945); Rev. Fac. Sci. Univ. Inst., B, 12 (1947).

- Goodwin and Srisukh, Biochem. J., 48 (1951). 